\title{
ANALISIS CAMPURAN SERAT PELEPAH TANGKAI PISANG KEPOK DENGAN RESIN KATALIS TERHADAP KEKUATAN TARIK
}

\author{
Rahbini $^{1}$, Heryanto Budiono Soemardi ${ }^{2}$, Sarjiyana ${ }^{3}$ \\ Jurusan Teknik Mesin Politeknik Negeri Malang ${ }^{123}$ \\ Jl. Soekarno - Hatta No. 9, Malang 65141, Indonesia \\ ${ }^{1}$ rahbini27@gmail.com, ${ }^{2}$ heryanto@ polinema.ac.id, ${ }^{3}$ an_sarjiyana50@yahoo.co.id
}

\begin{abstract}
Abstrak
Kekuatan pada bahan adalah parameter untuk menunjukkan sifat mekanik bahan yang ditentukan berdasarkan ketahanannya menopang gaya-gaya luar. Dalam ilmu bahan dikenal berbagai pengertian kekuatan yang bergantung pada berapa jauh gaya-gaya luar menimbulkan dampak terhadap bahan tersebut. Bahan resin dan katalis adalah sebuah polimer yang dibuat oleh industri kimia dan digunakan dalam berbagai aplikasi, diantaranya pengemasan, tekstil (contohnya tali, pakaian dalam termal, dan karpet), sedangkan pelepah tangkai pisang dari pohon banyak kandungan air belum digunakan dibidang teknik. Dengan adanya campuran serat pelepah tangkai pisang dengan resin katalis disebut bahan komposit. Komposit adalah suatu bahan padat yang dihasilkan dari gabungan dua atau lebih bahan yang berbeda untuk memperoleh sifat-sifat yang lebih baik yang tidak dapat diperoleh dari setiap komponennya. Metoda pengujian bahan komposit dilakukan dengan cara bahan dicetak dengan ukuran panjang, tebal dan lebar sesuai standar. Material tersebut dijepit atas bawah seterusnya alat uji menarik benda uji sehingga didapatkan nilai kekuatan tarik maksimal $10,2 \times 105 \mathrm{~kg} / \mathrm{m}^{2}$.
\end{abstract}

Keywords: composite, mixture of kepok banana, catalyst resin, tension stress

\begin{abstract}
The strength of material is a parameter to show mechanical material characteristic, which is determined based on the endurance of supporting external force. In materials science, it is know as the various meanings of strength based on how far external force causes the impact on the material. Resin material is a polymer produced by chemical industry and is used in various applications, among other are packing, textile (example: rope, thermal clothing, and carpet), while banana stalk which contain water has not been used in engineering. The mixture of banana stalk fiber with catalyst resin is called composite. Composite is a solid material produced by the combination between two or more diffrent materials to obtain better characteristic which cannot be obtained from every component.Testing method of composite is done by being pressed with long, thick, wide size based on the standard. The up and down part of the material is clamped and then the testing instrument pulls the tested object so that can show maximum pulling power of $10.2 \times 10^{5} \mathrm{~kg} / \mathrm{m}^{2}$ with a speed of $100 \mathrm{~mm} / \mathrm{minute}$.
\end{abstract}

Keywords: composite, mixture of kepok banana, catalyst resin, tension stress

\section{PENDAHULUAN}

\section{A. Latar Belakang Masalah}

Material komposit yang melibatkan dua atau lebih jenis pengisi dalam matriks disebut komposit hibrid [2]. Dengan komposit hibrid yang mengandung dua atau lebih pengisi, maka keunggulan dari suatu pengisi dapat melengkapi kelemahan pengisi lainnya Silvia [4]. Bahan resin tidak selalu digunakan peralatan rumah tangga namun resin dapat juga digunakan bentuk lainnya seperti campuran bahan cat kendaraan, lem, dll Harper [8]. Campuran resin dan serat pelepah tangkai pisang kepok upaya peningkatan nilai tambah suatu kekuatan komponen alternatif kebutuhan suku cadang kendaraan. Tentunya bahwa bahan komposit yang terbuat dari resin dan serat pelepah tangkai pisang Nopriantina [3] agar mempunyai kekuatan tambah dibandingkan tanpa serat tangkai pisang. Komposit tersebut dapat membatu untuk memndapatkan kekuatan lebih sangat memungkinkan digunakan pada bidang-bidang lainnya seperti kelistrikan, kedokteran teknik, dan teknik lainnya. Berdasarkan pertimbangan di atas kami mengadakan penelitian untuk mengetahui kekuatan tarik dari bahan komposit berupa campuran serat pelepah tangkai pisang kepok dengan resin pada pengujian tegangan tarik dalam skala laboratorium.

Perbandingan Kekuatan Tarik

Penelitian berikutnya komposit polipropilena dengan pengisi serat pandan dan serat batang pisang dalam daapat diketahui kekuatan tariknya Moulida [9].

\section{B. Perumusan Masalah}

Perumusan masalah kekuatan adalah: 
1) Bagaimana hasil kekuatan bahan campuran serat pelepah tangkai pisang dengan resin.

2) Bagaimanan menguji kekuatan bahan komposit yang terbuat dari campuran serat pelepah tangkai pisang dengan resin.

\section{Batasan Masalah}

Pembahasan penelitian dibatasi pada,

1) Uji kekuatan untuk bahan uji dilakukan uji tarik.

2) Benda uji bentuk pejal flat ukuran $2 \times 12,5 \times 75$ mm standar ASTM D-4762

3) Bahan benda uji dari bahan komposit.

\section{Tujuan Penelitian}

Tujuan penelitian dilakukan untuk:

Menganalisa kekuatan bahan yang ditinjau dari kekuatan tarik.

\section{E. Manfaat Penelitian}

Diharapkan setelah penelitian ini selesai dapat bermanfaat diantaranya:

1. Bagi peneliti dalam penelitian yang dilakukan merupakan penerapan teori-teori peningkatan kompetensi di bidang kekuatan bahan.

2. Hasil penelitian ini dapat dijadikan sebagai bahan studi kasus bagi peneliti lainnya dan acuan bagi mahasiswa serta dapat memberikan bahan referensi bagi pihak perpustakaan sebagai bacaan.

3. Bagi pembaca, sebagai bahan referensi dalam pengembangan penelitian lebih lanjut.

\section{TINJAUAN PUSTAKA}

\section{A. Penelitian sebelumnya}

Beberapa peneliti terdahulu tentang kekuatan tarik pada penelitian tentang pengaruh ketebalan serat pelepah pisang kepok (Musaparadisiaca) terhadap sifat mekanik material komposit poliester - serat alam. Dalam penelitian ini digunakan metode hand lay-up untuk pembuatan spesimen komposit dengan mengacu pada ASTM D-4762 sedangkan karakterisasi kuat tekan mengacu pada ASTM D-695 dan kuat tarik mengacu pada ASTM D-638.

Tegangan maksimum tali dari serat batang pisang pada diameter $10 \mathrm{~mm}$ yaitu pada orde $14 \times 10^{5} \mathrm{~kg} / \mathrm{m}^{2}$.hingga $16 \times 10^{5} \mathrm{~kg} / \mathrm{m}^{2}$. Dengan tegangan maksimum yang cukup tinggi, tali berbahan dasar serat batang pisang memiliki potensi yang tinggi sebagai produk yang memiliki nilai guna tinggi Yuliono [6].

Pengaruh kontaminasi Saliva terhadap kekuatan tarik antara resin komposit dengan jaringan dentin Resin komposit merupakan salah satu bahan restorasi sewarna gigi yang menjadi pilihan saat ini. Penggunaan resin komposit antara lain untuk gigi anterior dan gigi posterior. Kontaminasi saliva merupakan hal yang sering terjadi dalam aplikasi resin komposit Soufyan [5].

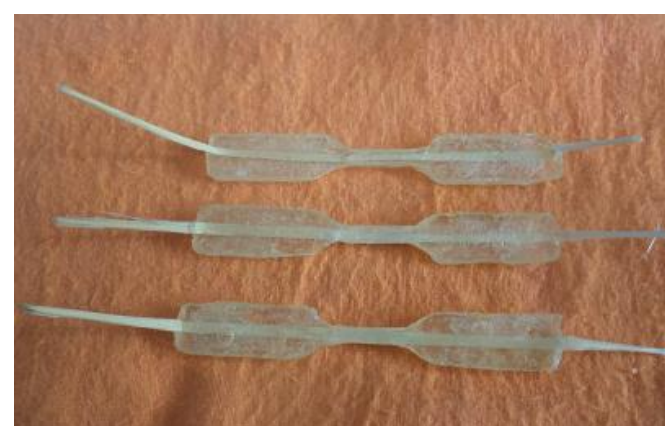

Gambar 1. Bentuk bahan komposit

\section{1. Kekuatan dan Regangan Sederhana}

Kekuatan Tarik

Kekuatan tarik pada umumnya terjadi pada rantai, tali, paku keling, dan lain-lain. Rantai yang diberi beban akan mengalami kekuatan tarik yang besarnya tergantung pada beratnya Beer [10].

2.2 Hukum Hooke Gere [7]

Berbunyi, "Jika benda dibebani dalam batas elastisnya, maka kekuatan berbanding lurus dengan regangannya". Secara matematis ditulis:

$$
\frac{\text { Tegangan }}{\text { Regangan }}=\mathrm{E}=\text { konstanta }
$$

2.3 Modulus Elastisitas (Modulus Young)

Kekuatan berbanding lurus dengan regangan, dalam daerah elastisnya [10], atau:

$$
\begin{gathered}
\sigma=E . x . \varepsilon \\
E=\frac{\sigma}{\varepsilon}
\end{gathered}
$$

dengan,

$\sigma:$ simbol kekuatan

$\epsilon$ : simbol regangan

E : konstanta proposionallitas atau disebut juga modulus elastis atau modulus Young

\subsection{Deformasi Benda Karena Gaya yang Bekerja} Misalkan,

$\mathrm{P}$ : beban atau gaya yang bekerja pada benda

$\mathrm{L}$ : panjang benda

A: luas penampang benda

$\sigma:$ simbol kekuatan

$\epsilon$ : simbol regangan

$\delta 1$ : deformasi benda

Kita tahu bahwa kekuatan tarik Gere [7]

$$
\sigma=\frac{P}{A}
$$

B. Hipotesis Nol $\left(\mathbf{H}_{\mathbf{0}}\right)$ adalah sbb.:

1. $\mathrm{H}_{01}$ : Tidak ada pengaruh yang signifikan antara gaya dan bahan komposit terhadap kekuatan tarik. 
2. $\mathrm{H}_{02}$ : Tidak ada pengaruh yang signifikan antara panjang dan bahan komposit terhadap kekuatan tarik

3.. $\mathrm{H}_{03}$ : Tidak ada pengaruh yang signifikan antara interaksi gaya dan panjang terhadap kekuatan tarik

C. Hipotesis alternatif ( $\left.\mathbf{H}_{1}\right)$ adalah sbb.:

1. $\mathrm{H}_{11}$ : ada pengaruh yang signifikan antara gaya dan bahan komposit terhadap kekuatan tarik.

2. $\mathrm{H}_{12}$ : ada pengaruh yang signifikan antara panjang dan bahan komposit terhadap kekuatan tarik

3. $\mathrm{H}_{13}$ : ada pengaruh yang signifikan antara interaksi gaya dan panjang terhadap kekuatan tarik

\section{III.METODE}

Penelitian ini dilakukan dengan metode sistimatis dengan cara tahap demi tahap yang diawali pemilihan bahan yang akan dibentuk menjadi benda uji. Pembuatan cetakan sesuai dengan stndar untuk bahan komposit atau non logam. Bentuk cetakan dibuat satu bagian tidak perlu dua bagian seperti satu tangkup maka metodenya sebagai berikut:

\section{Bahan dan Alat Penelitian}

Bahan spesimen

Bahan yang diperlukan adalah serat tangkai pisang dan resin katalis. Peralatan yang digunakan alat uji tarik.

\section{Pembuatan spesimen}

Mempersiapkan bahan komposit serat tangkai pisang dan resin. Membuat cetakan specimen dari aluminium dengan ketebalan $8 \mathrm{~mm}$ dan kedalaman cetakan untuk specimen $2 \mathrm{~mm}$. Mengukur serat tangkai pisang tebal dan panjang dengan menggunakan jangka sorong. Mengukur densitas serat dan resin dengan menggunakan timbangan digital dan gelas ukur. Sebelum resin dituangkan, terlebih dahulu seluruh permukaan cetakan dilapisi dengan grease agar specimen mudah dikeluarkan. Serat tangkai pisang dimasukkan ke cetakan dibuat 3 tahap. Tahap 1 serat tangkai pisang 1 biji, tahap 2 serat tangkai pisang 2 biji, tahap 3 serat tangkai pisang 3 biji. Tuangkan resin sampai penuh pada masing-masing cetakan sampai rata. Ukuran specimen dan benda cetakan Gambar 2 dan 3 rv $T$

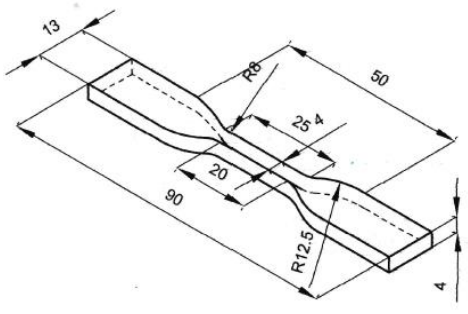

Ukuran benda kerja uji tarik

Gambar 2. Ukuran specimen

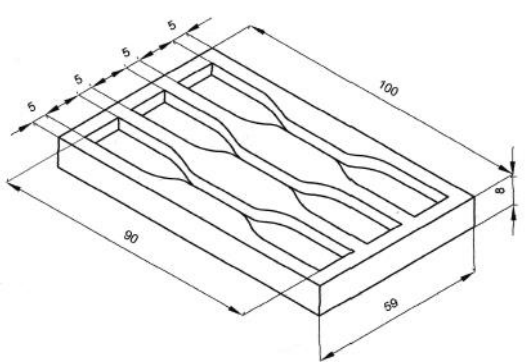

Gambar 3. Bentuk cetakan benda uji

Susunan bahan komposit terdiri atas serat tangkai pelepah pisang dan resin katalis 97\%:3\%. Perbandingan resin dengan pengeras cairan resin $99 \%: 1 \%$. Setelah specimen mengering kira 3 menit, specimen dikeluarkan dan dibersihkan dari grease yang menempel. Kemudian lakukan perbaikan pada specimen jika bentuk specimen belum rata.

\section{XIII.HASIL DAN PEMBAHASAN}

\section{A. Hasil Penelitian.}

Data hasil penelitian dianalisis dicatat berdasarkan hasil pengukuran dengan menggunakan grafik untuk menganilisis parameter beban dan kecepatan perlakuan terhadap kekuatan tarik, yang dihasilkan.seperti table 1 di bawah ini.

\section{TABEL 1. DATA KEKUATAN TARIK}

\begin{tabular}{|c|c|c|c|c|}
\hline \multirow{2}{*}{$\begin{array}{c}\text { Kecepatan tarik } \\
\text { m/men }\end{array}$} & $\begin{array}{c}\text { Tanpa } \\
\text { lapis }\end{array}$ & \multicolumn{4}{|c|}{ Jumlah lapis } \\
\cline { 2 - 5 } & \multicolumn{2}{|c|}{ Tegangan tarik maksimum } & Lapa \\
\hline \multirow{5}{*}{50} & 9 & 4 & 3 & 9 \\
\hline & 8 & 2 & 12 & 7 \\
\cline { 2 - 5 } & 8 & 3 & 10 & 8 \\
\cline { 2 - 5 } & 9 & 4 & 11 & 9 \\
\cline { 2 - 5 } & 8 & 4 & 10 & 8 \\
\hline \multirow{5}{*}{ Rata-rata } & 8,4 & 3,4 & 9,2 & 8,2 \\
\hline \multirow{5}{*}{100} & 9 & 11 & 11 & 5 \\
\cline { 2 - 5 } & 6 & 6 & 9 & 7 \\
\cline { 2 - 5 } & 7 & 9 & 10 & 7 \\
\cline { 2 - 5 } & 8 & 9 & 11 & 6 \\
\cline { 2 - 5 } & 7 & 10 & 10 & 6 \\
\hline Rata-rata & 7,4 & 9 & 10,2 & 6,2 \\
\hline \multirow{5}{*}{200} & 10 & 5 & 9 & 7 \\
\cline { 2 - 5 } & 10 & 10 & 7 & 3 \\
\cline { 2 - 5 } & 9 & 8 & 7 & 6 \\
\cline { 2 - 5 } & 8 & 8 & 8 & 5 \\
\cline { 2 - 5 } & 10 & 9 & 9 & 7 \\
\hline \multirow{5}{*}{ Rata-rata } & 9,4 & 8 & 8 & 5,6 \\
\hline
\end{tabular}

\section{B. Analisa Data}

Sebelum diadakan analisis data statistik, maka al pertama yang sangat penting adalah menganalisa distribusi dari data yang ada, yang sangat berguna untuk mengevaluasi kecocokan teknik statistik yang akan digunakan untuk uji hipotesis maupun pembuatan model. Dalam percobaan yang telah dilakukan maka dalam penelitian menggunakan uji statistik one wy anova [1] dengan grafis seperti Gambar 5 menunjukkan gambar 
grafik normal probability bahwa kedua faktor beban dan kecepatan tarik berpengaruh secara signifikan terhadap kekuatan. Semakin panjang benda uji semakin meningkat besar kekuatannya.

Setelah dilakukan proses analisis ditampilkan bentuk grafik seperti Gambar 4 menunjukkan bahwa respon besar tegangan tarik bila perlakuan kecepatan tarik semakin meningkat maka sebarannya semakin meningkat pula.

Bentuk lainnya dari hasil gambaran seperti Gambar 4 bahwa bentuk gambar grafik dari nilai rata-rata kekuatan tarik dari hasil beban dan kecepatan tarik pada titik nol sangat signifikan pengaruhnya terhadap kekuatan tarik. Bentuk grafik kecepatan tarik menunjukkan bahwa parameter beban maupun kecepatan tarik pada benda uji akan dapat memberi nilai perubahan besar kekuatan. Kondisi yang membuat meningkatnya kekuatan tentu disebabkan besar gaya dan kecepatan tarik. Pada tegangan maksimum terletak pada lapis 2 terjadi pada kecepatan tarik $100 \mathrm{~mm} /$ menit menunjukkan grafik titik-titiknya naik diantara titik 0 dan 3 dititik 2 .

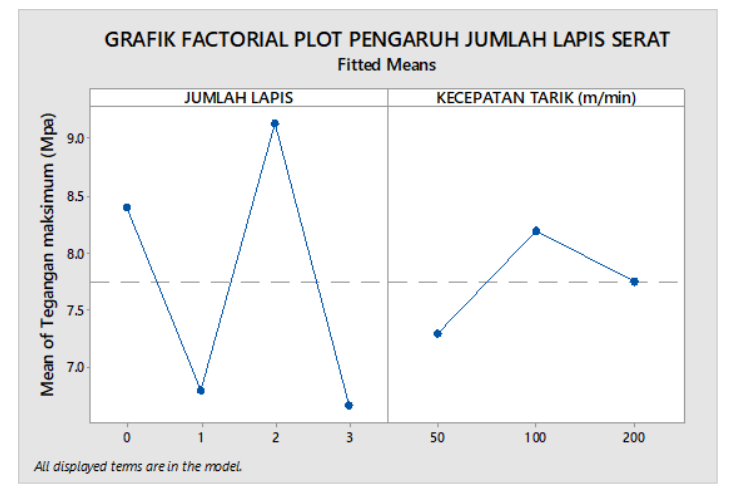

Gambar 4. Grafik pengaruh beban dan kecepatan tarik thd tegangan tarik

Pengaruh jumlah 2 lapis dan kecepatan tarik 100 m/detik katagori kecepatan sedang maka tegangan tarik yang diperoleh semakin besar Gambar 4.

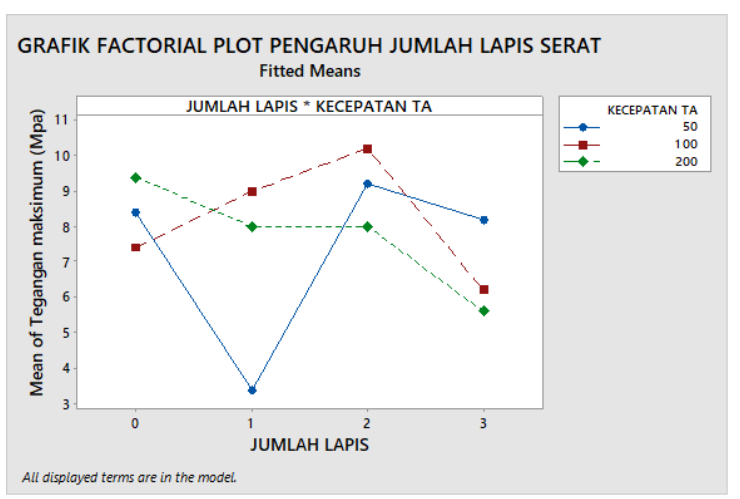

Gambar 5. Grafik pengaruh beban dan kecepatan tarik thd tegangan tarik

Pengaruh jumlah lapis dan kecepatan tarik Gambar 5
1. Tanpa lapis dengan kecepatan $200 \mathrm{~m} / \mathrm{menit}$ didapatkan tegangan tarik besar $9,5 \times 10^{5} \mathrm{~kg} / \mathrm{m}^{2}$.

2. Dengan lapis 1 dengan kecepatan $100 \mathrm{~m} / \mathrm{menit}$ didapatkan tegangan tarik besar $9,0 \times 10^{5} \mathrm{~kg} / \mathrm{m}^{2}$.

3. Dengan lapis 2 dengan kecepatan $\mathrm{m} / \mathrm{menit}$ didapatkan tegangan tarik besar $10,2 \times 10^{5}$ $\mathrm{kg} / \mathrm{m}^{2}$.

4. Dengan lapis 3 dengan kecepatan $50 \mathrm{~m} / \mathrm{menit}$ didapatkan tegangan tarik besar $8,9 \times 10^{5} \mathrm{~kg} / \mathrm{m}^{2}$.

Dari grafik tersebut diatas didapatkan tegangan paling rendah didapatkapan pada jumlah 1 lapis dengan kecepatan $50 \mathrm{~m} /$ menit tegangan tarik $3,4 \times 10^{5} \mathrm{~kg} / \mathrm{m}^{2}$. Tegangan maksimum didapatkan pada jumlah 2 lapis dengan kecepatan $100 \mathrm{~m} /$ menit tegangan tarik $10,2 \times 10^{5}$ $\mathrm{kg} / \mathrm{m}^{2}$.

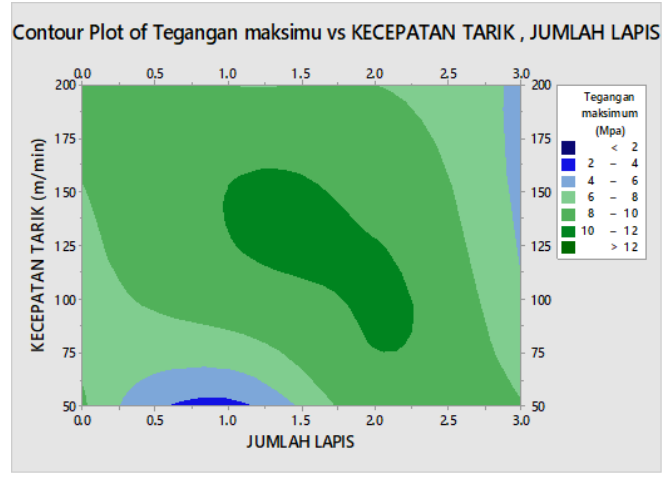

Gambar 6. Contour plot of tegangan maksimum vs kecepatan tarik, jumlah lapis

Pada grafik contour Gambar 6 tersebut diatas berwarna dasar hijau diantaranya hijau muda, hijau sedang dan hijau tua. Bermacam-macam warna hijau diklasifikasi besaran tegangan tarik dan kecepatan tarik benda uji. Didapatkan tegangan tarik paling besar terletak pada warna hijau pekat $10,2 \times 10^{5} \mathrm{~kg} / \mathrm{m}^{2}$. dan paling rendah 3,4 $\mathrm{x} 10^{5} \mathrm{~kg} / \mathrm{m}^{2}$

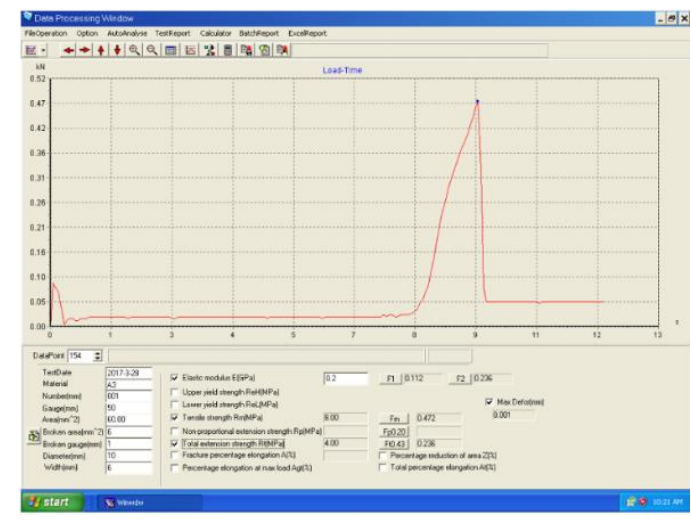

Gambar 7. Tegagan tarik dan beban

Tegangan tarik pada benda uji tanpa tambahan pelepah tangkai pisang seperti Gambar 7, didapatkan kekuatan tarik rata-rata $8,0 \times 10^{5} \mathrm{~kg} / \mathrm{m}^{2}$. pada beban $470 \mathrm{~kg}$ pada kecepatan tarik $50 \mathrm{~m} /$ menit. 


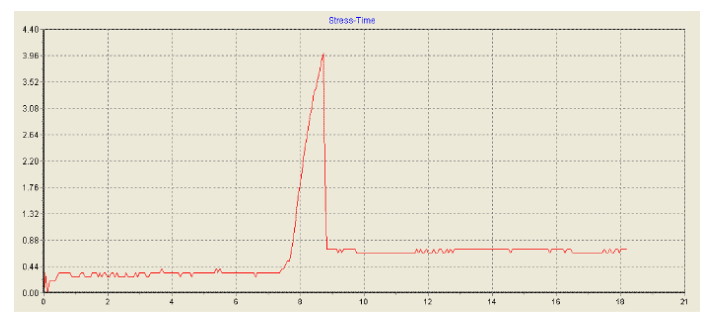

Gambar 8 grafik tegangan tarik jumlah 1 lapis kec. 50 $\mathrm{m} / \mathrm{menit}$

Tegangan tarik pada benda uji dengan tambahan jumlah 1 lapis pelepah tangkai pisang seperti Gambar 10, didapatkan kekuatan tarik rata-rata $3,96 \times 10^{5} \mathrm{~kg} / \mathrm{m}^{2}$ pada beban $240 \mathrm{~kg}$ pada kecepatan tarik $50 \mathrm{~m} /$ menit

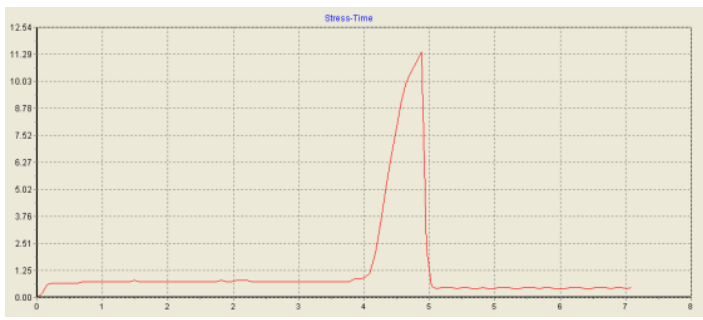

Gambar 9 grafik tegangan tarik jumlah 2 lapis kec. 100 $\mathrm{m} / \mathrm{menit}$

Tegangan tarik pada benda uji dengan tambahan jumlah 2 lapis pelepah tangkai pisang seperti Gambar 11 didapatkan kekuatan tarik rata-rata $10,2 \times 10^{5} \mathrm{~kg} / \mathrm{m}^{2}$ pada beban $680 \mathrm{~kg}$ pada kecepatan tarik $100 \mathrm{~m} / \mathrm{menit}$. Pada grafik dari awal $0-1$ terjadi garis proposional didapatkan tegangan tarik $0,9 \times 10^{5} \mathrm{~kg} / \mathrm{m}^{2}$. Grafik $0-4$ didapatkan garis panjang mendatar dikarenakan menerima gaya tetap benda uji semakin memanjang. Titik 4 mulai ada perubahan grafik naik proposional mencapai titik puncak $11,29 \times 10^{5} \mathrm{~kg} / \mathrm{m}^{2}$. Selanjutnya grafik mulai menurun titik 5 -7 dengan arah garis kekanan dan mendatar.

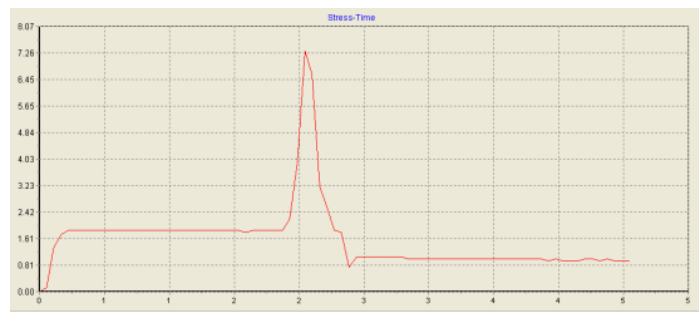

Gambar 10 grafik tegangan tarik jumlah 3 lapis kec. $200 \mathrm{~m} / \mathrm{menit}$

Tegangan tarik pada benda uji dengan tambahan jumlah 3 lapis pelepah tangkai pisang seperti Gambar 12, didapatkan kekuatan tarik rata-rata $7,26 \times 10^{5} \mathrm{~kg} / \mathrm{m}^{2}$ pada beban $440 \mathrm{~kg}$ pada kecepatan tarik $200 \mathrm{~m} /$ menit.

\section{Pembahasan}

\section{Benda uji mengalami kekuatan tarik}

Benda uji pada saat proses penarikan dengan variasi kecepatan tarik yang menyebabkan benda uji akan mengalami perubahan bentuk penampang. Besar kekuatan tergantung sifat bahan sesuai dengan tabel 1 hasil eksperimen dimana kekuatan benda uji sangat berpengaruh pada pembebanan dan kecepatan rata-rata. Dari tabel 1 dihitung rata-rata menunjukkan bahwa pengaruh beban dan kecepatan sangat signifikan perubahan kekuatan tarik.

\section{Kekuatan tarik}

Kekuatan tarik disebut juga mampu tarik adalah gaya yang berja pada benda uji arah vektor tegak lurus pada penampang pada saat mengalami penarikan.

Kekuatan tarik biasanya berhubungan erat dengan nilai pemanjangan saat putus yang diperoleh pada uji kekuatan tarik. Nilai kekuatan tarik dapat memiliki nilai yang sama apabila material yang diujikan berada dalam keadaan solid. Suatu material dikatakan homogen apabila material tersebut memiliki sifat yang sama disetiap titik tanpa bergantung pada lokasi. Pada uji kekuatan tarik, suatu material diberikan tegangan berupa tarikan yang berkonsentrasi pada suatu titik lokal tertentu, sehingga kekuatan tarik material akan bergantung pada jenis bahan yang bersangkutan pada titik tertentu tersebut, sedangkan pada uji kekuatan tarik, suatu material diberikan tegangan berupa tarikan yang berkonsentrasi pada seluruh material (homogen) pada seluruh titik, sehingga patahan akan mulai terjadi ketika penampang mulai ada perubahan mengecil saat itulah terjadi kekuatan minimal dan maksimal mencapai titik kekuatan tarik maksimumnya. Diantara sekian jumlah lapis serat pelepah tangkai pisang dari hasil uji tarik ternyata pada 2 lapis serat yang paling maksimum tegangannya.

\section{Kecepatan tarik}

Kecepatan tarik dalam proses pengujian sesuai spesifikasi peralatan yang ada bahwa untuk menguji kekuatan tarik variabel yang diberikan adalah beban dan kecepatan tarik. Beban yang diberikan 3 macam yaitu $400 \mathrm{mkg}, 1000 \mathrm{~kg}$, $20.000 \mathrm{~kg}$, sedangkan kecepatan terdiri pilihan 50 $\mathrm{m} /$ menit, $100 \mathrm{~m} /$ menit dan $200 \mathrm{~m} /$ menit.

\section{PENUTUP}

A. Kesimpulan

1. Tanpa tambahan pelepah tangkai pisang kepok didapatkan tegangan tarik rata-rata $8,0 \times 10^{5} \mathrm{~kg} / \mathrm{m}^{2}$ dengan kecepatan tarik $50 \mathrm{~m} /$ menit.

2. Dengan tambahan jumlah 1 lapis tegangan tarik ratarata minimal $3,96 \times 10^{5} \mathrm{~kg} / \mathrm{m}^{2}$ dengan kecepatan 50 $\mathrm{m} / \mathrm{menit}$. 
3. Dengan tambahan jumlah 2 lapis tegangan tarik ratarata maksimum $10,2 \times 10^{5} \mathrm{~kg} / \mathrm{m}^{2}$ jumlah 2 lapis dengan kecepatan $100 \mathrm{~mm} / \mathrm{menit}$.

4. Dengan tambahan jumlah 3 lapis tegangan tarik ratarata sedang $8,0 \times 10^{5} \mathrm{~kg} / \mathrm{m}^{2}$ dengan kecepatan 200 $\mathrm{mm} /$ menit.

\section{B. Saran}

1. Penelitian awal ini dapat dilanjutkan ke penelitian berikutnya untuk mendapatkan nilai-nilai kekuatan tarik.

2. Jumlah benda uji sebaiknya lebih dari 60 buah.

3. Pada proses pengujian benda uji sebaiknya permukaan flat dan rata.

\section{DAFTAR PUSTAKA}

[1] Grant, Eugene I. And S. Leavenworth, Rihard, 1989. Pengendalian Mutu Statistik, Erlangga, Jakarta.

[2] Jawaid,Khalil M. H.P.S., Khanam, P. Noorunnisa dan A. Abu Bakar., 2011, Hybrid Composites Made from Oil Palm Empty Fruit Bunches / Jute Fibres: Water Absorption, Thickness Swelling and Density Behaviours, J Polym Environ 19: 106-109.

[3] Nopriantina Noni, Astuti, 2013 Pengaruh Ketebalan Serat Pelepah Pisang Kepok (Musa Paradisiaca) Terhadap Sifat Mekanik Material Komposit Poliester-Serat Alam, Jurnal Fisika Unand Vol. 2, No. 3, ISSN 2302-8491, Jurusan Fisika FMIPA Universitas Andalas Kampus Unand, Limau Manis, Padang, 25163

[4] Silvia, Castiqliana, 2015, Pengujian Kekuatan Tarik Dan Kekuatan Tarik Komposit Hibrid Resin Bekas Kemasan Gelas Jenis Polipropilena/ Serbuk Kayu Kelapa Termodifikasi/Serbuk Serat Kaca Tipe E,Jurnal Teknik Kimia USU, Vol. 4, No. 3

[5] Soufyan A., D.J. Indrani, M.Erlinda, 2008, Pengaruh Kontaminasi Saliva Terhadap Kekuatan Tarik Antara Resin Komposit Dengan Jaringan Dentin, Indonesian Journal of Dentistry 2008; 15 (2):131134, ISSN 1693-9697, Fakultas Kedokteran Gigi, Universitas Indonesia, Jakarta

[6] Yuliono Eko Nugroho, Agus Yulianto dan Mahardika Prasetya Aji, 2013, Kuat Tarik Tali Berbahan Dasar Serat Batang Pisang, Jurnal Fisika Vol. 3 No. 1, 2013, FMIPA Universitas Negeri Semarang Jalan Raya Sekaran Gunungpati Semarang

[7] Gere James M. and Barry J. Goodno, 2009, Mechanics of Materials, Seventh Edition, ISBN-13: 978-0-534-55397-5 Printed in the United States of America

[8] Harper Charles A, 2006, Handbook of Plastic Processes, ISBN-13: 978-0-471-66255-6 (cloth), Printed in the United Stated of America

[9] Moulida, 2006, Perbandingan Kekuatan Tarik Komposit Polipropilena dengan Pengisi Serat Pandan dan Serat Batang Pisang, Jurnal Teknologi Proses, ISSN 1412-7814 USU

[10] Beer Ferdinand, 2012, Mechanics of Materials, Published by McGraw-Hill, a business unit of The
McGraw-Hill Companies, Inc., 1221 Avenue of the Americas, New York. 